\title{
Unraveling Mystery of the Painful Lumbar Intervertebral Disc
}

\author{
Col Shashivadhanan* \\ Department of Neurosurgery, Army Hospital Research \& Referral, India
}

Submission: January 24, 2018; Published: June 14, 2018

"Corresponding author: Col Shashivadhanan, Department of Neurosurgery, Army Hospital Research \& Referral, Delhi, India, Email: drshashivadhanan@gmail.com

\begin{abstract}
Traditional concepts for treatment of lumbar disc degeneration have aimed at symptomatic relief by removing the offending disc and limiting motion in the lumbar spine. Understanding the pathophysiological basis of disc degeneration is essential for the development of treatment strategies that target the underlying mechanisms of disc degeneration rather than the downstream symptom of pain. Researchers are working on novel treatment strategies which aim to induce disc regeneration or to replace the degenerated disc. These strategies involve stem cells, growth factors, and gene therapy. At present, treatment options for degenerative disc disease remain suboptimal, and the novel treatment strategies are not accepted as the standard of care. Is there any difference between the aging and the degenerated disc? Is Discogenic pain the main cause of back pain, How do we explain back pain in the absence of any imaging abnormality. Or for that matter why do we find asymptomatic patient with features of gross degenerative changes in MRI of lumbar spine. Are some individuals genetically more predisposed to develop lumbar degenerative disc disease? These are some questions which need to be answered with a firm scientific conviction.

Adding on to the complexity is the path physiology of pain mechanism. The pain of Low back pain which is nociceptive during the acute stage acquires central sensitization on assuming chronicity. There occurs a functional reorganization within the pain matrix of the brain. A brief outline is provided of our present understanding of, the anatomical basis of pain mechanism based on the current, available body of literature. In current scenario it is also proposed that since the cause of low back pain is multimodal, medical care providers should adopt a multi-disciplinary model in order to provide pain relief. The treatment modalities should include physical therapy, pharmacotherapy, interventional local pain modulating therapy and surgical intervention.
\end{abstract}

\section{Evolving Concepts Pain and Treatment Strategies}

Despite the inherent challenge in elucidating the specific etiology of chronic low back pain, diagnostic procedures can reveal its source in up to $90 \%$ of patients. De Palma et al elucidated that the prevalence of zygapophysial joints, sacroiliac joints, and lumbar discs were $31 \%, 18 \%$, and $42 \%$, respectively [1]. Crock was the first to propose that isolated internal disc disruption (IDD) without nerve root irritation could cause discogenic pain [2] 26\%-42\% of chronic low back pain patients have IDD [1-4]. Our current understanding believes IDD to be a distinct clinical entity which needs to be distinguished from other pain causing entities [5]. A recent study has classified discogenic low back pain into two types. They are annular disruptioninduced low back pain (IAD) and internal endplate disruption (IED)-induced low back pain. These two distinct types have been fully supported by clinical and theoretical bases. Treatment of IAD is removal of the offending disc and that of IED is lumbar spinal fusion [6]. Psychosocial factors play an important role in determining back pain behavior but are unlikely to predict as to who will experience back pain in the first place [7]. Back pain seems to have a genetic basis. As on date 40 genes have been found which are involved in development of Disc [8].

\section{Pathophysiology}

Nam V. Vo and colleagues have proposed a biochemical cascade of disc aging by dividing it into three phases:

a) Accumulation of damage to bimolecular,

b) Aberrant cellular response to damage,

c) Loss of biologic structure and function [9]. Studies have yet to prove any distinct dissimilarity in imaging morphology between an aged disc and a degenerated disc $[10,11]$.

\section{Anatomy of Low Back Pain}

Bogduk \& Twomey [12] have extensively described the innervation of spinal structures [12]. The dorsal ramus of each spinal nerve divides into three branches. Lateral branches supply the iliocostalis lumborum muscle and the skin; intermediate branches supply the longissimus muscle and the apophyseal joints. Medial branches supply the apophyseal joints, the interspinous and multifidus muscles, and also the interspinous ligament. Each medial branch supplies the apophyseal joints at its own level and also the joint below. Vertebral body endplates 
have the potential to be painful as they carry sensory innervations [13]. The posterior longitudinal ligament contains an extensive plexus of nerve fibers which also have free and encapsulated endings [14]. The grey rami communicants arise from the lumbar sympathetic trunks to join the ventral rami of the lumbar spinal nerves there by forming a mixed nerve called the sin vertebral nerve. The sin vertebral nerve supplies the posterior and poster lateral annulus fibroses, and the posterior longitudinal ligament. De Palma and colleagues conducted studies on various pain sensitive structures and concluded that zygapophysial joints, sacroiliac joints, and lumbar discs contributed to pain by $31 \%$, $18 \%$, and $42 \%$, respectively [15].

\section{Biochemical Pain Sensitization}

There is growing evidence that pain arises from disrupted degenerated discs, but not from old dehydrated discs. However, even the most severe degenerative changes can sometimes be observed in people who have no back pain, suggesting that pain perception depends on biochemical/central pain sensitization mechanisms which are yet to be fully established [16]. It is also possible that some individuals with degenerated and narrowed discs do not experience pain as the load bearing is transferred to neural arch. Many patients reporting to the pain physician have an element of chronicity which implies that the pain mechanism has a nociceptive and central component. Central sensitization is defined as "an amplification of neural signaling within the central nervous system (CNS) that elicits pain hypersensitivity" [17]. A key brain area implicated in pain neuromatrix is the Amygdale.

The amygdale along with the hippocampus and anterior cingulated cortex are implicated in the development of pain memories. The development of such a pain memory applies to all movements that once provoked pain. This results in protective behaviors (e.g. antalgic posture movement patterns, altered lumbo pelvic motor control and probably also, avoidance of particular movements like forward bending) [18]. Even preparing for such 'dangerous' movements can evoke activation of the fearmemory center in the brain thereby eliciting pain without any peripheral nociceptive input. This will also prompt the patient to adopt a protective motor control strategy [19]. Why only a subgroup of low back pain patients develop central sensitization is still not very clear. Pain Neurosciences have also revealed that Glial over activity and poor sleep may play an important role in central sensitization $[20,21]$. Contemporary pain Neurosciences aims at identifying the relevant pain mechanisms in a patient of chronic low back pain. Knowing these mechanisms will help them in devising physical therapy and postural exercises which can retrain the pain memories and also target sleep disturbances.

\section{Aberrant Neuro Vascularization}

Branches of the sin vertebral nerve, the spinal nerves, and gray rami communicantes have been the targets for most pain intervention procedures. Studies have demonstrated painful discs to have increased proliferation of nerve fibers and blood vessels in the disc which is otherwise an a neural structure. Studies have shown a correlation between aberrant neuro vascularization and expression of neurotropins [22]. Studies suggest that an imbalance between the matrix metalloproteinase-3 (MMP-3) and tissue inhibitor of metalloproteinase-1 (TIMP-1) results in dehydration of disc leading to buckling of the annular lamellae. This leads to increased focal segmental mobility and shear stress to the annular wall. Delamination and fissuring within the annulus can result. Annular delamination and annuar fissuring are two separate and distinct events [21-23]. These degenerative disc changes affect the normal external load bearing, predisposing patient to back strain, even within physiological limits of weight bearing and motion [24,25].

\section{Degenerative Disc and Degenerative painful Disc are Different}

The degenerative disc and the degenerative painful disc have a subtle difference. Early degenerative changes encompass biochemical and metabolic changes with aging without any structural failure. The term degenerative disc disease is applied to a painful degenerative disc with structural failure which may include radial tear of the annulus fibroses, herniated intervertebral disc, calcification or damage to the end plate, and internal disc disruption [26-28].

\section{The Nociceptive Neurotransmitters}

Stimulation of nociceptors in the annulus fibrosis causes nociceptive pain. Substance P, calcitonin gene-related peptide, and vasoactive intestinal polypeptide immunoreactive nerve fibers are present in the absolute outer layers of the annulus fibroses of a normal disc and they are implicated in causation of pain during low back pain [29]. Degenerative changes in the discs leading to abnormal motion amplify the pain response to nociceptors resulting in a condition called peripheral sensitization [30]. Lactic acid accumulation causes a low $\mathrm{pH}$ which stimulates the neurogenic and non-neurogenic pain mediator leading to provocative pain. There is abundant infiltration of mast cells in the granulation tissue zones. This triggers the inflammatory cascade within the disc and surrounding structures. It's been postulated that this inflammation induced tissue degradation, causes signal release of certain substances like tumor necrosis factor and interleukins, which go on to play a role in the development of back pain. The finding that degenerative disc contains a high concentration of Phospholipids A2 which is related to of arachidonic acid cascade, indirectly proves the above postulate [31].

\section{Functional Pathology}

On living subjects, spinal loading depends on the precise manner in which a person moves [32] and cadaveric spine experiments show that orientation of vertebra or posture plays a vital role in weight distribution within spinal tissue [33-35]. This concept of 'functional pathology' explains the conventional advice on 'good' and 'bad' posture. 


\section{Environmental factors}

In 2011, William Sambrook [36] and colleagues evaluated the influence of environmental factors on disc degeneration [36]. Chemical exposure due to smoking has been postulated to influence Disc degeneration, although the association is not very strong [37]. Nicotine which impairs blood flow could be possible cause leading to early disc degeneration [38].

\section{Genetic Factors}

Many genes have been implicated in degenerative cascade. They include genes that code for collagens I, IX, and XI, interleukin 1 (IL-1), aggrecan, the vitamin D receptor, matrix metalloproteinase 3 (MMP-3), and other proteins [39]. It has been established that multiple gene interactions and its probable gene environmental cross interaction orchestrates the Degenerative process [40].

\section{Diagnosis}

Plain X-Ray and MRI of the lumbosacral spine indicate the health of the disc and help in identifying structural abnormality. However they fail to pinpoint the pain generator which, are generally more than one and progress in time as a dynamic entity. Crux of treatment lies in identifying these pain generators and addressing each one of them based on their pain generating potential. Provocative discography may help in identifying the culprit disc. The diagnostic criteria for IDD established by the International Association for the Study of Pain (IASP) includes, emergence of a concordant pain response during discography, internal annular disruption demonstrated by CT after discography (CTD) and at least one adjacent disc without concordant pain [41]. Validation of provocative discography remains questionable and carries the risk of accelerating the degenerative cascade [4244]. A thorough neurological examination with imaging findings is the best tool we have as on date to identify the pain generators and formulate a treatment strategy.

\section{Treatment Strategies}

These include

a) Physical therapy and other conservative modalities.

b) Minimally invasive interventions for pain management.

c) Surgical interventions.

d) Novel Therapies.

Physical therapy: Physical Therapy, exercise, manipulation, and back school seem to have an important role in alleviating the symptoms of back pain but their long term effects remain to be proving [45]. Exercise therapy proposed by McKenzie is a popular treatment for low back pain. Clinical studies prove McKenzie method to be more effective than manipulation for patients with chronic low back pain [46].

Minimally invasive pain interventions: The interventional pain management services have found to have a steady increase in its clientele in the past decade. From 2000 to 2011 the interventional pain management services have increase by $228 \%$. This fact only proves that pain mitigation does not rest wholly within the realm of the spine surgeon [47]. The intervention spectrum includes

a) Epidural steroids

b) Facet interventions

c) Intradiscal Therapies

d) Vertebral Augmentation

e) Implantable Therapies

Epidural procedures continue to be debated regarding their effectiveness, indications, and medical necessity. Recent systematic reviews indicated that effectiveness of epidural injections for treatment of discogenic low back pain was satisfactory. It is believed that neural blockade achieved by this interventional procedures, alters or interrupts nociceptive input, the reflex mechanism of the afferent fibers, self-sustaining activity of the neurons, and the pattern of central neuronal activities [48]. As alternative treatments, percutaneous treatments directed at altering the internal mechanics or innervation of the disc by heat (intradiscal electrothermal annuloplasty, IDET, and biacuplasty) have recently been advocated), but data supporting their use does not seem very strong [49].

Surgical Intervention: The present armamentarium that exist with the spine surgeon includes minimally invasive disc volume reducing procedures, neural decompressive procedures, lumbar fusion procedures, disc arthroplasty and posterior dynamic stabilization. The motion preserving procedures claim the benefit of preventing adjacent segment disease [50]. Results of clinical trials evaluating disc arthroplasty with conventional fusion procedures have shown similar outcomes when compared with circumferential fusion for the treatment of discogenic pain [51]. Posterior dynamic stabilization works on the principle of limiting motion in the inter space thereby reducing discogenic pain $[52,53]$. In spite of this 29 to $47 \%$ patients develop adjacent segment disease [54, 55].

Novel therapies: Therapies directed towards disrupting the pro inflammatory signaling cascade or breaking the nerve conduction pathways can transform a painful disc into an asymptomatic disc there by greatly improving the quality of life. However they fail to stop or reverse the progress of disc degeneration [56]. The newer modalities under research include biologic growth factors, stem cells, and gene transplant. They may reverse the degenerating process to some extent but fail to translate to commensurate clinical improvement [57]. Stem Cell transplantation is currently emerging as a promising treatment strategy for DDD [58]. The stem cells being studied include the chondrocyte progenitor cells, adipocyte progenitor cells and bone marrow derived stem cells. These stem cells increase the extracellular matrix in animal experiments. In post 
discectomy pain it offers significant pain reduction probably by rehydrating the desiccated disc [59].The issue challenging stem cell transplantation is provisioning of nutritional supply for the transplanted cell to replicate [60].

Researchers are focusing on employing a gene vector system to effect transduction of gene which will stop degeneration or even initiate regenerative process thereby restoring normal structure and function. TGF-1B was the first gene is experimentally delivered to the IVD in an animal model so as to help in its regeneration [61]. ADAMTS5 small interference RNA was successfully used in a rabbit model to suppress degradation of NP tissue [62]. In present scenario, growth factors, metallo proteinases inhibitors, transcription factors, can be used as targets for gene therapy $[63,64]$. In vivo studies need to validate the above findings before Gene therapy establishes as an accepted modality of treatment [65].

\section{Conclusion}

With newer insights into the path mechanics of disc degeneration and advancement in pain neurosciences, our understanding of the painful disc has definitely improved. There seems to be no single triggering factor which initiates the Degenerative cascade. What follows is accumulation of damaged biomolecules which further instigate an aberrant cellular response to damage, leading to loss of biologic structure and function. The exact mechanism and correlation of the various cascading systems are unclear at present. These mechanisms lead to structural and biochemical changes within the disc leading to increase in the nociceptive response and spinal instability. The integration of our existing knowledge of path physiology still leaves many questions unanswered. But further research will help us solve the mystery of the painful disc.

Treatment of low back pain requires a multidisciplinary approach. Lack of evidence based literature does not mean lack of effectiveness of a particular modality of therapy. For pain we have no objective tests and also no controls. Identification of the pain generator and instituting appropriate strategy seems the logical approach as on date. Present understanding of path physiology suggests that the pain generators undergo a change in their anatomical location as well as molecular configuration with the progression of degenerative disc disease process. One must also keep in mind that when there is degeneration of disc is not an isolated phenomenon. It is often accompanied by degeneration of surrounding spine tissue. They too contribute to pain and instability. Hence the treatment strategies also need to be directed taking these factors into consideration. A musculoskeletal, vertebral or radicular pain in the acute stage may transform into neuropathic pain or over a prolonged period into chronic pain syndrome. The traditional approach of motioneliminating fusion surgery, which may be effective for the treatment of pain in some cases, may also increase the rate of degeneration at adjacent spinal motion segments.
Furthermore, this strategy does not halt the progression of the degenerative cascade of events that leads to pain and disability. So despite its undeniable significance, lumbar fusion surgery as a treatment of LBP has to be regarded suboptimal, as it targets the symptom of pain rather than its causes. The modern molecular biology era has brought revolutionary advances in fields such as genomics, nanotechnology, stem cell biology, gene therapy, and tissue engineering, which together hold tremendous therapeutic potential for clinical applications in degenerative disorders such as DDD. These newer modalities have the potential to become the standard of care in the near future. As on date the astute clinician must realize that winning over the painful degenerative disc disease requires a multidisciplinary approach. Sometimes you win, other times you learn.

\section{References}

1. De Palma MJ, Ketchum JM, Saullo T (2011) What is the source of chronic low back pain and does age play a role? Pain Med 12(2): 224-233.

2. Crock HV (1970) A reappraisal of intervertebral disc lesions. Med J Aust 1(20): 983-989.

3. Schwarzer AC, Aprill CN, Derby R, Fortin J, Kine G, et al. (1976) The prevalence and clinical features of internal disc disruption in patients with chronic low back pain. Spine 20(1): 1878-1883.

4. Manchikanti L, Singh V, Pampati V, Damron KS, Barnhill RC, et al. (2001) Evaluation of the relative contributions of various structures in chronic low back pain. Pain Physician 4(4): 308-316.

5. Singh K, Ledet E, Carl A (2005) Intradiscal therapy: a review of current treatment modalities. Spine 30(17 Suppl): S20-S26.

6. Bao Gan Peng (2013) Pathophysiology, diagnosis, and treatment of discogenic low back pain. World J Orthop 4(2): 42-52.

7. Michael A Adam (2004) Biomechanics of back pain. Education and practice 22(4): 178-188.

8. Sivakamasundari V, Lufkin T (2012) Bridging the Gap: Understanding Embryonic Intervertebral Disc Development. Cell Dev Biol 1(2): 103.

9. VO NV, Hartman RA, Patil PR, Risbud MV, Kletsas D, et al. (2016) Molecular Mechanisms of Biological Aging in Intervertebral Discs. J Orthop Res 34(8): 1289-1306.

10. Boos N, Weissbach S, Rohrbach H, Weiler C, Spratt KF, et al. (2002) Classification of age-related changes in lumbar intervertebral discs: 2002 Volvo Award in basic science. Spine 27(23): 2631-2644.

11. Miller JA, Schmatz C, Schultz AB (1988) Lumbar disc degeneration: correlation with age, sex, and spine level in 600 autopsy specimens. Spine 13(2): 173-178.

12. Bogduk N Clinical (1997) Anatomy of the lumbar spine and sacrum. ( $3^{\text {rd }}$ edn), Churchill Livingstone, Edinburgh: London.

13. Brown MF, Hukkanen MV, McCarthy ID, Redfern DR, Batten JJ, et al. (1997) Sensory and sympathetic innervation of the vertebral endplate in patients with degenerative disc disease. J Bone Joint Surg Br 79(1): 147-153.

14. Groen GJ, Baljet B, Drukker J (1990) Nerves and nerve plexuses of the human vertebral column. Am J Anat 188(3): 282-296.

15. De Palma MJ, Ketchum JM, Saullo T (2011) What is the source of chronic low back pain and does age play a role? Pain Med 12(2): 224-233.

16. Olmarker K, Nutu M, Storkson R (2003) Changes in spontaneous behavior in rats exposed to experimental disc herniation are blocked by selective TNF-alpha inhibition. Spine 28(15): 1635-1641. 
17. Woolf CJ (2011) Central sensitization: implications for the diagnosis and treatment of pain. Pain 152(3 Suppl): S2-S15.

18. Nijs J, Lluch Girbes E, Lundberg M, Malfliet A, Sterling M (2015) Exercise therapy for chronic musculoskeletal pain: Innovation by altering pain memories. Man Ther 20(1): 216-220.

19. Yong Hing K, Kirkaldy Willis WH (1983) The pathophysiology of degenerative disease of the lumbar spine. Orthop Clin North Am 14(3): 491-504.

20. Tucker K, Larsson AK, Oknelid S, Hodges P (2012) Similar alteration of motor unit recruitment strategies during the anticipation and experience of pain. Pain 153(3): 636-643.

21. Loggia ML, Chonde DB, Akeju O, Arabasz G, Catana C, et al. (2015) Evidence for brain glial activation in chronic pain patients. Brain 138(3): 604-615.

22. Mullington JM, Simpson NS, Meierewert HK, Haack M (2010) Sleep loss and inflammation. Best Pract Res Clin Endocrinol Metab 24(5): 775784

23. J García Cosamalón, del Valle ME, Calavia MG, García-Suárez O, LópezMuñiz A, et al. (2010) Intervertebral disc, sensory nerves and neurotrophins: who is who in discogenic pain? J Anat 217(1): 1-15.

24. Dean DD, Martel-Pelletier J, Pelletier JP, Howell DS, Woessner JF (1989) Evidence for metalloproteinase and metalloproteinase inhibitor imbalance in human osteoarthritis cartilage. J Clin Invest 84(2): 678685

25. Komiya Y (1992) Immuno histo chernical localization of tissue inhibitor of metallo proteinases (TIMP) and stromelysin in human joint synovium. Jpn J Rheum Joint Surg 11: 59-70.

26. Horner HA, Urban JP (2001) Volvo Award Winner in Basic Science Studies: effect of nutrient supply on the viability of cells from the nucleus pulposus of the intervertebral disc. Spine 26(23): 2543-2549.

27. Fardon, David F (2001) Nomenclature and classification of lumbar disc pathology. Spine 26(5): 461-462.

28. Solovieva S, Lohiniva J, Leino-Arjas P, Raininko R, Luoma K, et al (2002) COL9A3 gene polymorphism and obesity in intervertebra disc degeneration of the lumbar spine: evidence of gene-environment interaction. Spine 27(23): 2691-2696.

29. Videman T, Battie MC, Gill K, Manninen H, Gibbons LE, et al. (1995) Magnetic resonance imaging findings and their relationships in the thoracic and lumbar spine. Insights into the etiopathogenesis of spinal degeneration. Spine 20(8): 928-935.

30. Konttinen YT, Gronblad M, Antti-Poika I, Seitsalo S, Santavirta S, et al. (1990) Neuroimmunohistochemical analysis of peridiscal nociceptive neural elements. Spine 15(5): 383-386

30. Brisby H (2006) Pathology and possible mechanisms of nervous system response to disc degeneration. J Bone Joint Surg Am 88(2): 68-71.

31. Franson RC, Saal JS, Saal JA (1992) Human disc phospholipase A2 is inflammatory. Spine 17(6): S129-S132.

32. Dolan P, Earley M, Adams MA (1994) Bending and compressive stresses acting on the lumbar spine during lifting activities. J Biomech 27(10): 1237-1248.

33. Pollintine P, Dolan P, Tobias JH, Adams MA (2004) Intervertebral disc degeneration can lead to 'stress shielding' of the anterior vertebral? 29(7): 774-782

34. Adams MA, Dolan P (1996) Time-dependent changes in the lumbar spine's resistance to bending. Clin Biomech 11(4): 194-200.

35. Adams MA, Dolan P, Hutton WC (1987) Diurnal variations in the stresses on the lumbar spine. Spine 12(2): 130-137.
36. Williams FM, Sambrook PN (2011) Neck and back pain and intervertebral disc degeneration: role of occupational factors. Best Pract Res Clin Rheumatol 25(1): 69-79.

37. Battié MC, Videman T (2006) Lumbar disc degeneration: epidemiology and genetics. J Bone Joint Surgery Am 88 Suppl 2: 3-9.

38. Iwahashi M, Matsuzaki H, Tokuhashi Y, Wakabayashi K, Uematsu Y (2002) Mechanism of intervertebral disc degeneration caused by nicotine in rabbits to explicate intervertebral disc disorders caused by smoking. Spine 27(13): 1396-1401.

39. Kalichman L, Hunter DJ (2008) The genetics of intervertebral disc degeneration. Associated genes. Joint Bone Spine 75(4): 388-396.

40. Zhang Y, Sun Z, Liu J, Guo X (2008) Advances in susceptibility genetics of intervertebral degenerative disc disease. Int J Biol Sci.

41. Merskey H, Bogduk N (1994) Classification of Chronic Pain Descriptions of Chronic Pain Syndrome and Definitions of Pain Terms. Seattle IASP Press, pp. 180-181.

42. Carragee EJ, Don AS, Hurwitz EL, Cuellar JM, Carrino J, et al. (2009) ISSLS prize winner: does discography cause accelerated progression of degeneration changes in the lumbar disc: a ten-year matched cohort study. Spine 34(21): 2338-2345.

43. Saboeiro GR (2009) Lumbar discography. Radiol Clin North Am 47(3): 421-433.

44. Carragee EJ, Tanner CM, Khurana S, Hayward C, Welsh J, et al. (2000) The rates of false-positive lumbar discography in select patients without low back symptoms. Spine 25(11): 1373-1381.

45. Carragee EJ (2005) Clinical practice. Persistent low back pain. N Engl J Med 352(18): 1891-1898.

46. Petersen T, Larsen K, Jacobsen S (2007) One-year follow-up comparison of the effectiveness of McKenzie treatment and strengthening training for patients with chronic low back pain: outcome and prognostic factors. Spine 32(26): 2948-2956.

47. Manchikanti L, Falco FJ, Singh V, Pampati V, Parr AT, et al. (2011) Utilization of interventional techniques in managing chronic pain in the Medicare population: Analysis of growth patterns from 2000 to 2011. Pain Physician 15(6): E969-E982.

48. Benyamin RM, Manchikanti L, Parr AT, Diwan S, Singh V, et al. (2012) The effectiveness of lumbar interlaminar epidural injections in managing chronic low back and lower extremity pain. Pain Physician 15(4): E363-E404.

49. Saal JA, Saal JS (2000) Intradiscal electrothermal treatment for chronic discogenic low back pain: a prospective outcome study with minimum 1-year follow-up. Spine 25(20): 2622-2627.

50. Song KJ, Choi BW, Jeon TS, Lee KB, Chang H (2011) Adjacent segment degenerative disease: is it due to disease progression or a fusionassociated phenomenon? Comparison between segments adjacent to the fused and non-fused segments. Eur Spine J 20(11): 1940-1945.

51. Zigler J, Delamarter R, Spivak JM, Linovitz RJ, Danielson GO, et al. (2007) Results of the prospective, randomized, multicenter food and drug administration investigational device exemption study of the ProDisc-L total disc replacement versus circumferential fusion for the treatment of 1-level degenerative disc disease. Spine 32(11): 1155-1162.

52. Hu Y, Gu YJ, Xu RM, Zhou LJ, Ma WH (2011) Short-term clinical observation of the Dynesys neutralization system for the treatment of degenerative disease of the lumbar vertebrae. Orthop Surg 3(3): 167175 .

53. Schaeren S, Broger I, Jeanneret B (2008) Minimum four-year followup of spinal stenosis with degenerative spondylolisthesis treated with decompression and dynamic stabilization. Spine 33(18): E636-E642. 
54. Schnake KJ, Schaeren S, Jeanneret B (2006) Dynamic stabilization in addition to decompression for lumbar spinal stenosis with degenerative spondylolisthesis. Spine (Phila Pa 1976) 31(4): 442-449.

55. Choi YS (2009) Pathophysiology of degenerative disc disease. Asian Spine J 3(1): 39-44.

56. An HS, Masuda K (2006) Relevance of in vitro and in vivo models for intervertebral disc degeneration. J Bone Joint Surg Am Series 88(2): 88-94.

57. Sheikh H, Zakharian K, De La Torre RP, Facek C, Vasquez A, et al (2009) In vivo intervertebral disc regeneration using stem cell-derived chondroprogenitors. J Neurosurg Spine 10(3): 265-272.

58. Hohaus C, Ganey TM, Minkus Y, Meisel HJ (2008) Cell transplantation in lumbar spine disc degeneration disease. Eur Spine J 17(4): S492-S503.

59. Urban JP, Smith S, Fairbank JC (2004) Nutrition of the intervertebral disc. Spine 29(23): 2700-2709.

60. Nishida K, Kang JD, Gilbertson LG, Moon SH, Suh JK, et al. (1999) Modulation of the biologic activity of the rabbit intervertebral disc by gene therapy: an in vivo study of adenovirus-mediated transfer of the human transforming growth factor $\beta 1$ encoding gene. Spine 24(23) 2419-2425.

This work is licensed under Creative

Commons Attribution 4.0 License
61. Seki S, Asanuma-Abe Y, Masuda K, Kawaguchi Y, Asanuma K, et al. (2009) Effect of small interference RNA (siRNA) for ADAMTS5 on intervertebral disc degeneration in the rabbit anular needle-puncture model. Arthritis Res Ther 11(6): R166.

62. Cui M, Wan Y, Anderson DG, Shen FH, Leo BM, et al. (2008) Mouse growth and differentiation factor-5 protein and DNA therapy potentiates intervertebral disc cell aggregation and chondrogenic gene expression. Spine J 8(2): 287-295.

63. Wallach CJ, Sobajima S, Watanabe Y, Kim JS, Georgescu HI, et al. (2003) Gene transfer of the catabolic inhibitor TIMP-1 increases measured proteoglycans in cells from degenerated human intervertebral discs. Spine 28(20): 2331-2337.

64. Paul R, Haydon RC, Cheng H, Ishikawa A, Nenadovich N, et al. (2003) Potential use of Sox 9 gene therapy for intervertebral degenerative disc disease. Spine 28(8): 755-763.

65. Nishida K, Suzuki T, Kakutani K, Yurube T, Maeno K, et al. (2008) Gene therapy approach for disc degeneration and associated spinal disorders. Eur Spine J 17(4): S459-S466.

Your next submission with Juniper Publishers will reach you the below assets

- Quality Editorial service

- Swift Peer Review

- Reprints availability

- E-prints Service

- Manuscript Podcast for convenient understanding

- Global attainment for your research

- Manuscript accessibility in different formats

( Pdf, E-pub, Full Text, Audio)

- Unceasing customer service

Track the below URL for one-step submission https://juniperpublishers.com/online-submission.php 